\title{
DETEKSI CEKAMAN OKSIDATIFAKIBAT TOKSISITAS KROM PADA Sonchus oleraceus L. MELALUI PENENTUAN SPESIES OKSIGEN REAKTIF SECARA SPEKTROFOTOMETRI DAN HISTOKIMIA
}

\author{
DETECTION OF OXIDATIVE STRESS DUE TO CHROMIUM TOXICITY ON \\ SONCHUS OLERACEUS L. BY SPECTROPHOTOMETRICALLY AND \\ HISTOCHEMICAL DETERMINATION OF REACTIVE OXYGEN SPECIES
}

\author{
Sri Kasmiyati ${ }^{1)}$ dan Sucahyo ${ }^{1)}$ \\ Diterima 21 Oktober 2014, disetujui 11 November 2014
}

\begin{abstract}
Increased production of reactive oxygen species or ROS is one of the common responses to a wide range of biotic and abiotic stresses. Increased production of ROS is outstripping endogenous antioxidant defense systems has been referred to as oxidative stress. Heavy metals are known to initiate ROS generation which is implicated as a oxidative stress. $\mathrm{Cr}$ is a toxic heavy metal that can generate $\mathrm{ROS}$ like $\mathrm{H}_{2} \mathrm{O}_{2}$ and $\mathrm{O}_{2}^{-}$which cause oxidative stress. In this study, chromium toxicity was studied to detect the oxidative stress on Sonchus oleraceus weed plants by the detection of superoxide anion and $\mathrm{H}_{2} \mathrm{O}_{2}$. Superoxide anion was detected by staining techniques with nitroblue tetrazolium (NBT) and hydrogen peroxide by Diaminobenzidine tetrahydrochloride (DAB) staining. Results indicated that the plants were grown in sand media generate the highest $(0.89 \mathrm{~A} / \mathrm{g} \mathrm{FW}$ and $3.23 \mathrm{~mol} / \mathrm{g} F W)$ than in soil media $(0.23 \mathrm{~A} / \mathrm{g} \mathrm{FW}$ and $2.11 \mathrm{~mol} / \mathrm{g} F W)$ superoxide anion $\left({ }^{*} \mathrm{O}_{2}^{-}\right)$ and $\mathrm{H}_{2} \mathrm{O}_{2}$ and soil containing textile sludge $(0.18 \mathrm{~A} / \mathrm{g} \mathrm{FW}$ and $2.66 \mathrm{~mol} / \mathrm{g} \mathrm{FW})$, respectively. At application of $10 \mathrm{mg} \mathrm{Cr}^{6+} / \mathrm{L}$ and $250 \mathrm{mg} \mathrm{Cr}^{3+} / \mathrm{L}$, the production of ${ }^{*} \mathrm{O}_{2}^{-}$and $\mathrm{H}_{2} \mathrm{O}_{2}$ in leaves of sonchus plants were significantly increased compared with the control plants. The highest production of $\mathrm{H}_{2} \mathrm{O}_{2}$ and ${ }^{*} \mathrm{O}_{2}^{-}$were showed in the leaves of sonchus plants grown in sand media with $\mathrm{Cr}^{6+}$ application. In this study, either $\mathrm{Cr}^{3+}$ or $\mathrm{Cr}^{6+}$ caused oxidative stress in Sonchus oleraceus weed plants. The result also showed that sonchus plants esposed to toxic $\mathrm{Cr}$ can suffer from oxidative stress leading to reduction of its fresh and dry plants biomass. NBT and DAB in an appropriate probe and significant value for monitoring the formation of $\mathrm{*O}_{2}^{-}$and $\mathrm{H}_{2} \mathrm{O}_{2}$ in plants.
\end{abstract}

Keywords: anion superoksida, $\mathrm{ROS}$, deteksi histokima, cekaman oksidatif, $\mathrm{H}_{2} \mathrm{O}_{2}$, Sonchus oleraceus

\section{PENDAHULUAN}

Pencemaran logam berat salah satunya krom di lingkungan akibat pembuangan limbah industri dan penggunaan pupuk serta pestisida sintetis secara berlebihan akan memberikan dampak terhadap munculnya cekaman oksidatif terhadap kehidupan tanaman. Salah satu logam berat yang bersifat toksik terhadap tanaman adalah krom yang dapat

\footnotetext{
${ }^{1)}$ Fakultas Biologi, Universitas Kristen Satya Wacana, Salatiga
} penulis untuk korespondensi, email: kas@staff.uksw.edu menimbulkan cekaman oksidatif. Adanya cekaman oksidatif pada tanaman dapat menghambat pertumbuhan dan perkembangan, menurunkan produktivitas bahkan dapat menyebabkan kematian. Salah satu faktor yang mempengaruhi toksisitas krom terhadap pertumbuhan tanaman adalah media tanam, karena sifat fisik, kimia dan biologi dari media tanam mempunyai peran penting dalam proses transformasi $\mathrm{Cr}$ dari bentuk toksik menjadi 
bebas dalam bentuk species oksigen reaktif(ROS) sebagai hasil samping dari metabolisme aerob yang berlangsung di berbagai kompartemen seluler seperti dinding sel (peroksidase dan poliamin oksidase), sitoplasma, peroksisom (xanthin oksidase), mitokondria dan kloroplas (Kumar dkk., 2014; Vianello dkk., 2007; Malecka dkk., 2009). Pembentukan ion-ion radikal bebas seperti ROS akan mengalami peningkatan apabila tanaman mengalami cekaman baik abiotik maupun biotik. Akumulasi ion radikal bebas dalam bentuk ROS pada konsentrasi tinggi akan merusak komponenkomponen seluler dan makromolekul termasuk membran plasma, asam nukleat dan protein. Pembentukan ROS juga mempunyai fungsi sebagai efektor dan regulator dalam proses kematian sel terprogram (Malecka dkk., 2014). Selain itu, pembentukan ROS dalam jumlah sangat besar pada sel/jaringan tumbuhan juga dapat dijadikan sebagai indikator adanya cekaman oksidatif yang dapat mengancam kelangsungan kehidupan tumbuhan.

Logam berat pada umumnya menginduksi pembentukan ROS baik secara langsung maupun melalui reaksi redoks. Krom merupakan logam yang bersifat non-redoks dan tidak terlibat dalam reaksi Fenton, namun dari hasil penelitian Shi dan Dalal (1989) dilaporkan bahwa Cr dapat berperan dalam reaksi Fenton, dibuktikan bahwa $\mathrm{Cr}$ memiliki karakter redoks. Berdasarkan hasil penelitiannya Strile, dkk. (2003) juga dilaporkan bahwa $\mathrm{Cr}^{6+}$ dan $\mathrm{Cr}^{5+}$ secara katalitik bersifat aktif dan memiliki kemampuan untuk membentuk ROS seperti radikal hidroksil $\left(\mathrm{OH}^{-}\right)$. Aktivitas katalitik $\mathrm{Cr}^{3+}$ lebih tinggi dalam sistem reaksi Fenton dibandingkan dengan logam yang lain seperti $\mathrm{Co}^{2+}$, $\mathrm{Cd}^{2+}, \mathrm{Zn}^{2+}, \mathrm{Mn}^{2+}$, dan $\mathrm{Fe}^{3+}$, tetapi lebih rendah dibanding $\mathrm{Cu}^{2+}$. Reaktivitas krom dapat disebabkan oleh interaksinya dengan gluthation, NADH dan $\mathrm{H}_{2} \mathrm{O}_{2}$, pembentuk radikal-radikal $\mathrm{OH}$ - di dalam sistem bebas sel (Shi dan Dalal, 1989). Pembentukan $\mathrm{H}_{2} \mathrm{O}_{2}, \mathrm{OH}^{-}$dan $* \mathrm{O}_{2}^{-}$pada kondisi stress krom telah banyak ditunjukkan pada berbagai jenis tumbuhan, dan memunculkan terjadinya stress oksidatif yang mengakibatkan kerusakan pada DNA, protein dan pigmen, serta menginisiasi terjadinya peroksidasi lipid (Panda dan Patra, 2000; Panda, 2003).

Diantara ion-ion radikal bebas yang tergolong dalam ROS, anion superoksida dan $\mathrm{H}_{2} \mathrm{O}_{2}$ merupakan dua species oksigen reaktif yang penting sebagai indikator adanya kerusakan atau toksisitas di dalam sel, serta sebagai indikator munculnya reaksi pertahanan terhadap berbagai kondisi cekaman lingkungan. Oleh karena itu perlu dikembangkan metode untuk penentuan kadar kedua species oksigen reaktif tersebut. Beberapa metode yang telah diterapkan adalah menggunakan probe spin superoksida-spesifik seperti assay dengan chemiluminescence, fluorescence dan spektrofotometer (Shulaev dan Oliver, 2006). Pengembangan metode deteksi secara langsung ROS secara in vivo dengan metode histokimia dapat dilakukan menggunakan ROS tracer dye yaitu nitroblue tetrazolium (NBT) untuk ${ }^{*} \mathrm{O}_{2}{ }_{2}$ dan 3,3 Diaminobenzidine (DAB) untuk $\mathrm{H}_{2} \mathrm{O}_{2}$. NBT dan DAB berfungsi sebagai substrat chromogenic, dan hasil reaksi warna yang terbentuk dapat diamati menggunakan mikroskop. Penelitian bertujuan untuk mendeteksi adanya cekaman oksidatif akibat toksisitas krom pada gulma Sonchus oleraceus pada media tanam yang berbeda melalui penentuan kadar ${ }^{*} \mathrm{O}_{2}^{-}$dan $\mathrm{H}_{2} \mathrm{O}_{2}$ secara spektrofotometri dan histokimia.

\section{METODE PENELITIAN}

Penelitian dilakukan secara eksperimental menggunakan bahan gulma Sonchus oleraceus yang diperoleh dari daerah Getasan, Kabupaten Semarang, adapun penanaman dilakukan menggunakan 3 media pertumbuhan meliputi pasir steril, tanah pertanian, dan tanah mengandung limbah sludge tekstil yang diperoleh dari salah satu industri tekstil di Salatiga dengan perbandingan 1:1 (tanah:sludge tekstil). Pemberian perlakuan krom dalam dua bentuk spesies $\mathrm{Cr}^{6+}$ dalam bentuk senyawa $\mathrm{K}_{2} \mathrm{Cr}_{2} \mathrm{O}_{7}$ dan $\mathrm{Cr}^{3+}$ dalam bentuk senyawa 
$\mathrm{CrCl}_{3}$ dengan konsentrasi $0 \mathrm{mg} \mathrm{Cr} / \mathrm{L}$ (sebagai kontrol), $5 \mathrm{mg} \mathrm{Cr} / \mathrm{L}$ untuk $\mathrm{Cr}^{6+}$, serta $250 \mathrm{mg} \mathrm{Cr} /$ $\mathrm{L}$ untuk $\mathrm{Cr}^{3+}$. Perlakuan $\mathrm{Cr}$ diberikan sebanyak $250 \mathrm{ml}$ dengan konsentrasi sesuai perlakuan pada media tanam sebanyak $750 \mathrm{mg}$. Perlakuan $\mathrm{Cr}$ dilarutkan dalam pupuk cair lengkap dan disiramkan pada media tanam, serta dibiarkan selama 2 hari sebelum ditanami Sonchus oleraceus. Setelah 2 hari, gulma Sonchus oleraceus umur 3 minggu ditanam pada masingmasing media kontrol dan perlakuan $\mathrm{Cr}$. Penanaman dilakukan sampai gulma S. oleraceus berumur \pm 3 bulan. Rancangan penelitian yang digunakan adalah RAK (rancangan acak kelompok) faktorial dengan 2 faktor perlakuan $\mathrm{Cr}$ dan jenis media tanam. Setiap perlakuan dengan 10 ulangan, setiap unit percobaan terdiri dari 1 gulma sonchus.

Pengamatan pertumbuhan tanaman berdasarkan pada penentuan biomassa basah dan kering. Akumulasi $\mathrm{Cr}$ di dalam tanaman ditentukan melalui pengukuran kandungan $\mathrm{Cr}^{6+}$ dan $\mathrm{Cr}$ total. Kandungan $\mathrm{Cr}^{6+}$ dalam tanaman ditentukan secara spektrofotometris menggunakan metode difenilkarbasid melalui pembacaan nilai serapan pada panjang gelombang $540 \mathrm{~nm}$ (Sharma dkk., 2011), sedangkan $\mathrm{Cr}$ total ditentukan dengan AAS (spektrofotometer serapan atom dengan pembacaan nilai serapan pada panjang gelombang $357,87 \mathrm{~nm}$ ). Cekaman oksidatif akibat perlakuan Cr pada tanaman $S$. oleraceus ditentukan melalui pengukuran level $* \mathrm{O}_{2}^{-}$dan $\mathrm{H}_{2} \mathrm{O}_{2}$ yang terbentuk secara spektrofotometris menggunakan sampel pucuk. Penentuan level $\mathrm{H}_{2} \mathrm{O}_{2}$ di dalam sel menurut metode Sergiev (1997) yang digunakan Bouazizi dkk. (2007), sedangkan $* \mathrm{O}_{2}^{-}$dengan metode Kumar dkk. (2014) dan Malecka dkk. (2014). Deteksi ${ }^{*} \mathrm{O}_{2}^{-}$yang terbentuk pada daun dilakukan secara histokimia menggunakan NBT sebagai substrat kromogenik dan hasil reaksi warna yang terbentuk setelah diinkubasi selama 1 jam diamati menggunakan mikroskop. Data level anion superoksida dan $\mathrm{H}_{2} \mathrm{O}_{2}$ dianalisis menggunakan analisis sidik ragam (ANOVA) dan dilanjutkan dengan uji Duncan pada taraf uji 5 persen. Uji korelasi Pearson dilakukan untuk mengetahui korelasi antar varibel, sedangkan data histokimia dianalisis secara deskriptif.

\section{HASIL DAN PEMBAHASAN}

\section{Biomassa tanaman}

Biomassa massa tanaman diukur berdasarkan berat basah dan berat keringnya. Pengukuran berat basah tanaman lebih mudah dilakukan, dapat menunjukkan aktivitas metabolisme, namun nilainya tidak konstan sebab dipengaruhi kandungan air dalam sel.

Pengukuran pertumbuhan yang lebih akurat adalah dengan mengukur berat kering dengan cara dikeringkan pada suhu $80^{\circ} \mathrm{C}$ selama 3 hari di dalam oven sehingga air yang terkandung dalam tanaman menguap. Setelah kering didinginkan dan ditimbang berulang sampai diperoleh berat konstan. Jika dibandingkan antara berat kering mula-mula dengan berat kering pada selang beberapa waktu maka dapat diketahui ada atau tidaknya pertumbuhan. Hasil berat kering merupakan keseimbangan antara fotosintesis dan respirasi.

Perlakuan $\mathrm{Cr}$ pada media tanam yang berbeda memberikan pengaruh secara nyata terhadap biomassa basah dan kering pada akar dan pucuk gulma Sonchus (Gambar 1 dan 2). Biomassa basah akar dan pucuk tanaman yang ditumbuhkan pada media pasir mengalami penurunan paling besar pada perlakuan $\mathrm{Cr}^{6+}$. Pada media tanah dan campuran tanah:sludge tekstil (1:1) tanaman sonchus menunjukkan biomassa basah akar dan pucuk lebih tinggi dibandingkan yang ditumbuhkan pada media pasir, meskipun sama-sama diberi perlakuan $\mathrm{Cr}$ dalam medianya. Bahkan pada media campuran tanah:sludge tekstil yang telah terdeteksi mengandung polutan $\mathrm{Cr}^{6+}$ pun masih menunjukkan biomassa akar dan pucuk lebih tinggi dibandingkan pada pasir. Hal ini menunjukkan bahwa pada media pasir, toksisitas $\mathrm{Cr}$ lebih tinggi dibandingkan dalam media tanah dan campuran tanah:sludge 
tekstil. Kandungan dan komposisi nutrien tanah dan sludge tekstil lebih punya kemampuan menopang pertumbuhan tanaman sonchus dengan adanya perlakuan Cr. Jumlah nutrien dan kebera-daan mikroorganisme yang bermanfaat bagi tanaman dalam media tanah, sludge tekstil, maupun campuran tanah:sludge tekstil mempunyai peran besar dalam menekan toksisitas Cr terhadap gulma S. oleraceus. Dibandingkan dengan pasir yang relatif bersifat inert (tidak mengandung nutrien), tanah dan sludge tekstil banyak mengandung nutrien yang dibutuhkan untuk pertumbuhan tanaman. Kandungan unsur hara esensial seperti N, P, K, $\mathrm{S}, \mathrm{Bo}, \mathrm{Cu}, \mathrm{Zn}$ dan lain-lain banyak ditemukan pada media tanah dan sludge. Sludge tekstil selain mengandung beberapa jenis logam berat yang tergolong $\mathrm{B}_{3}$, dilaporkan mengandung unsur-unsur yang dibutuhkan oleh tanaman diantaranya nitrogen, fosfor, kalium, dan sulfur dalam jumlah yang sangat besar (Herawati dkk., 2008).

A.

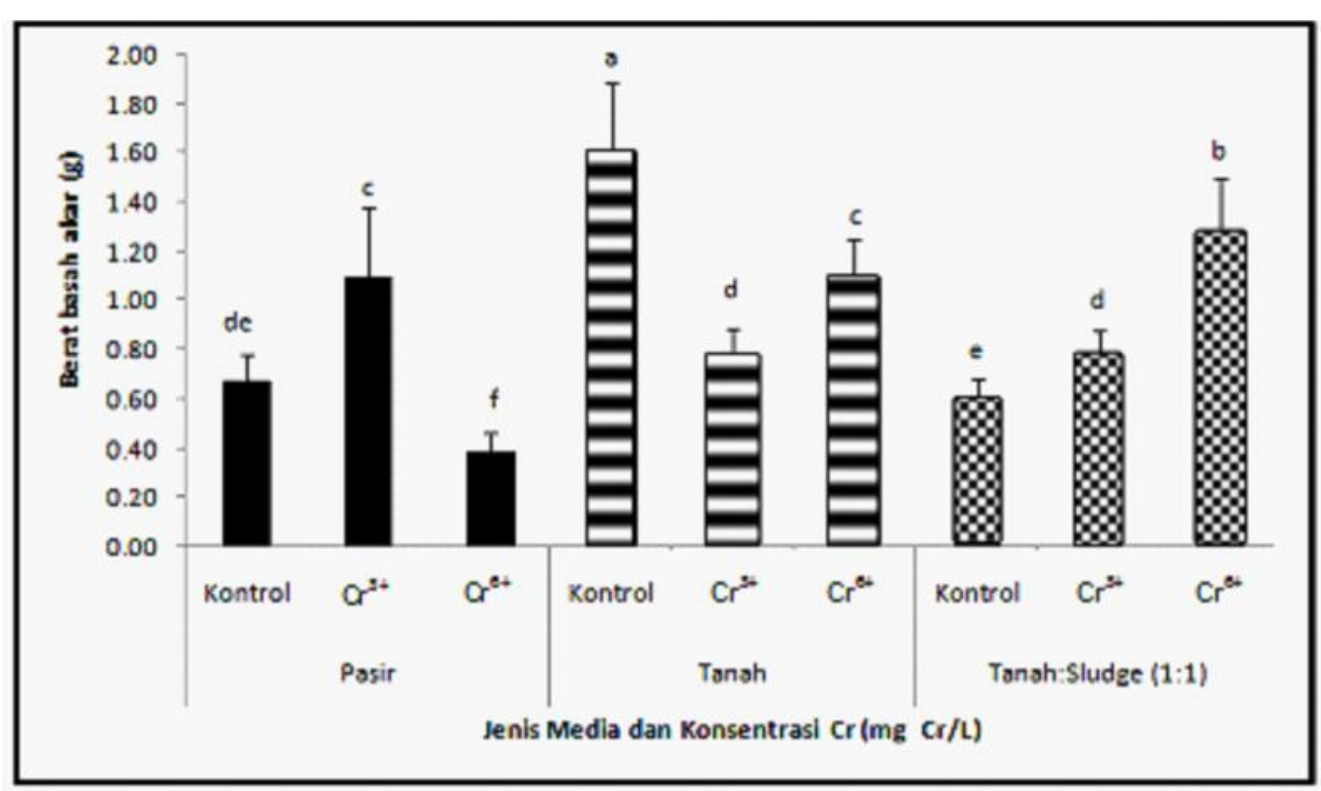

B.

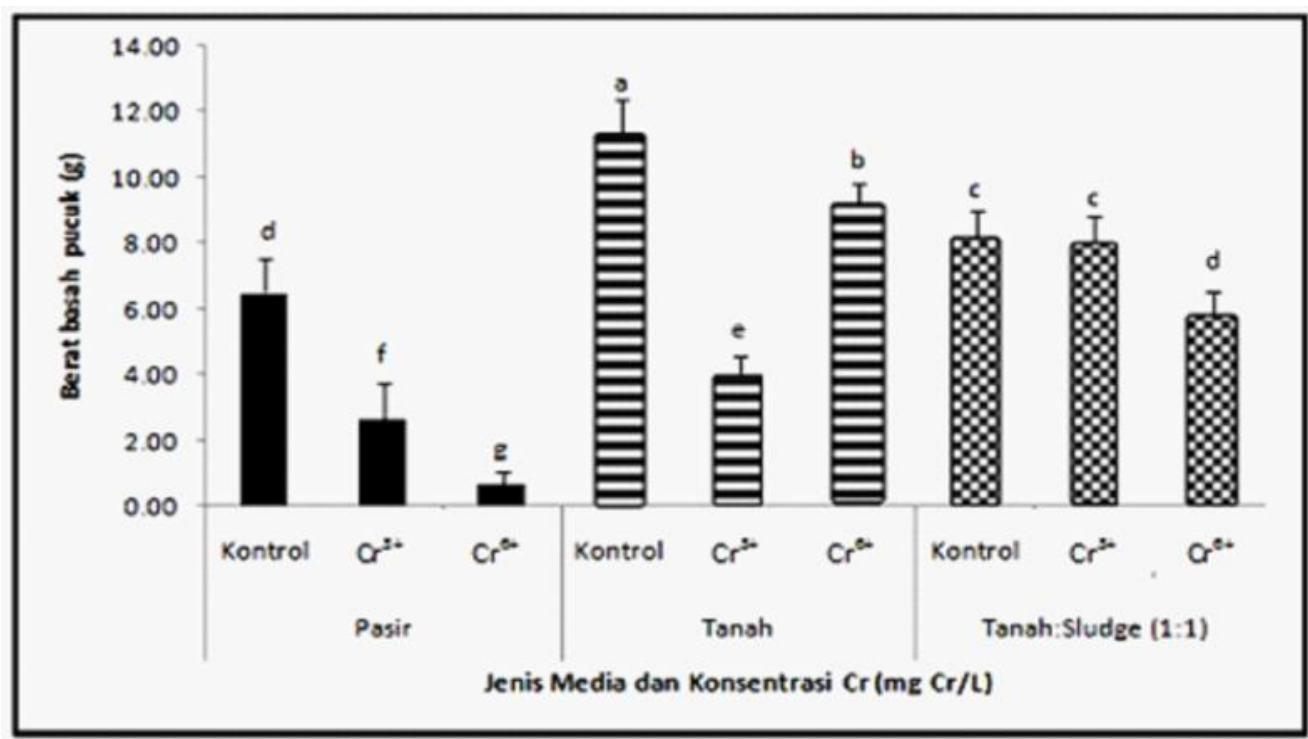

Gambar 1.Efek interaksi antara jenis media tanam dan perlakuan Cr terhadap biomassa basah akar (A) dan pucuk (B) tanaman S. oleraceus 
Media tanam dan $\mathrm{Cr}$ menunjukkan efek interaksi terhadap biomassa kering akar dan pucuk gulma sonchu. Gambar 2 menunjukkan pengaruh nyata kedua perlakuan tersebut terhadap biomassa kering tanaman. Pengaruh $\mathrm{Cr}$ terhadap biomassa kering akar dan pucuk menunjukkan pola yang hampir sama dengan biomassa basah, dimana tanaman sonchus yang ditumbuhkan pada media pasir mengalami penurunan biomassa kering akar dan pucuk paling besar pada perlakuan $\mathrm{Cr}^{6+}$ dibandingkan pada tanah dan campuran tanah:sludge tekstil. Biomassa kering pucuk pada semua perlakuan $\mathrm{Cr}$ mengalami penurunan dibandingkan kontrol, baik pada media pasir, tanah maupun campuran tanah:sludge tekstil.

A.

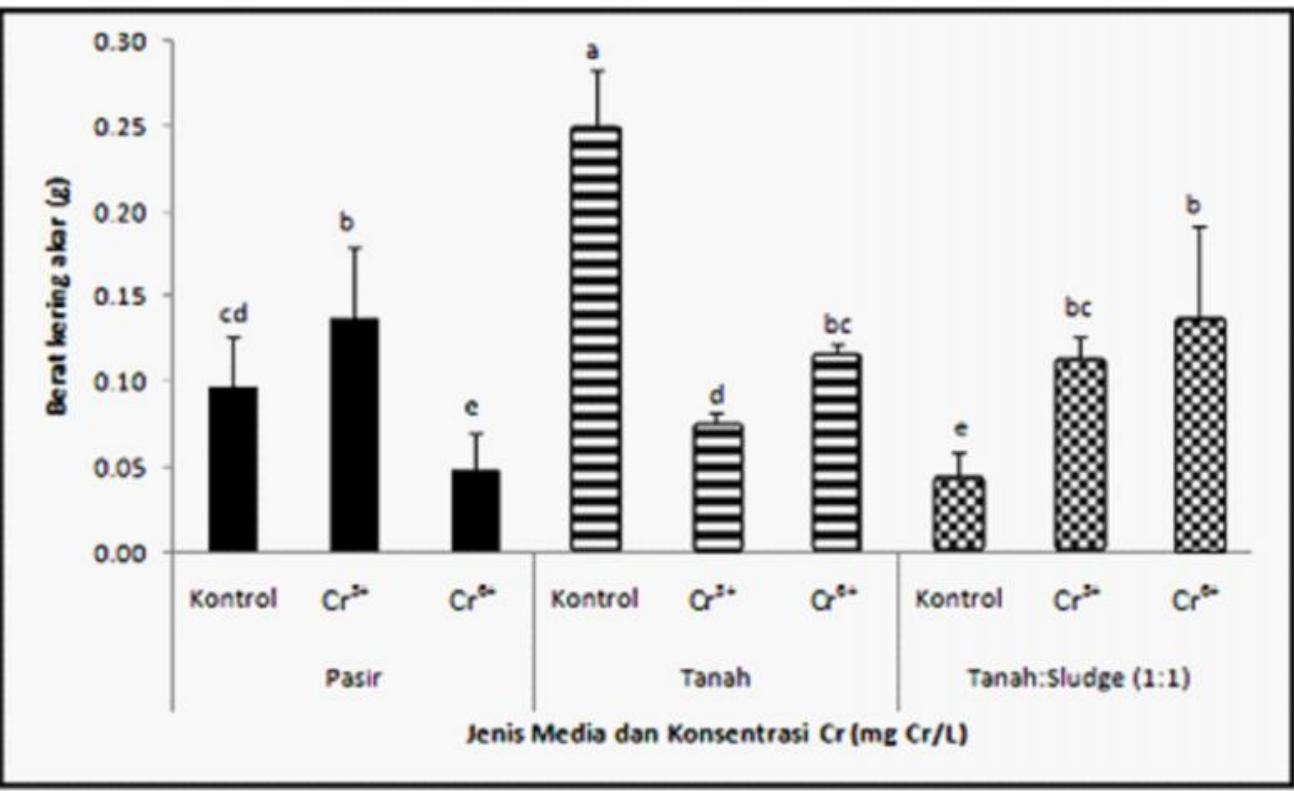

B.

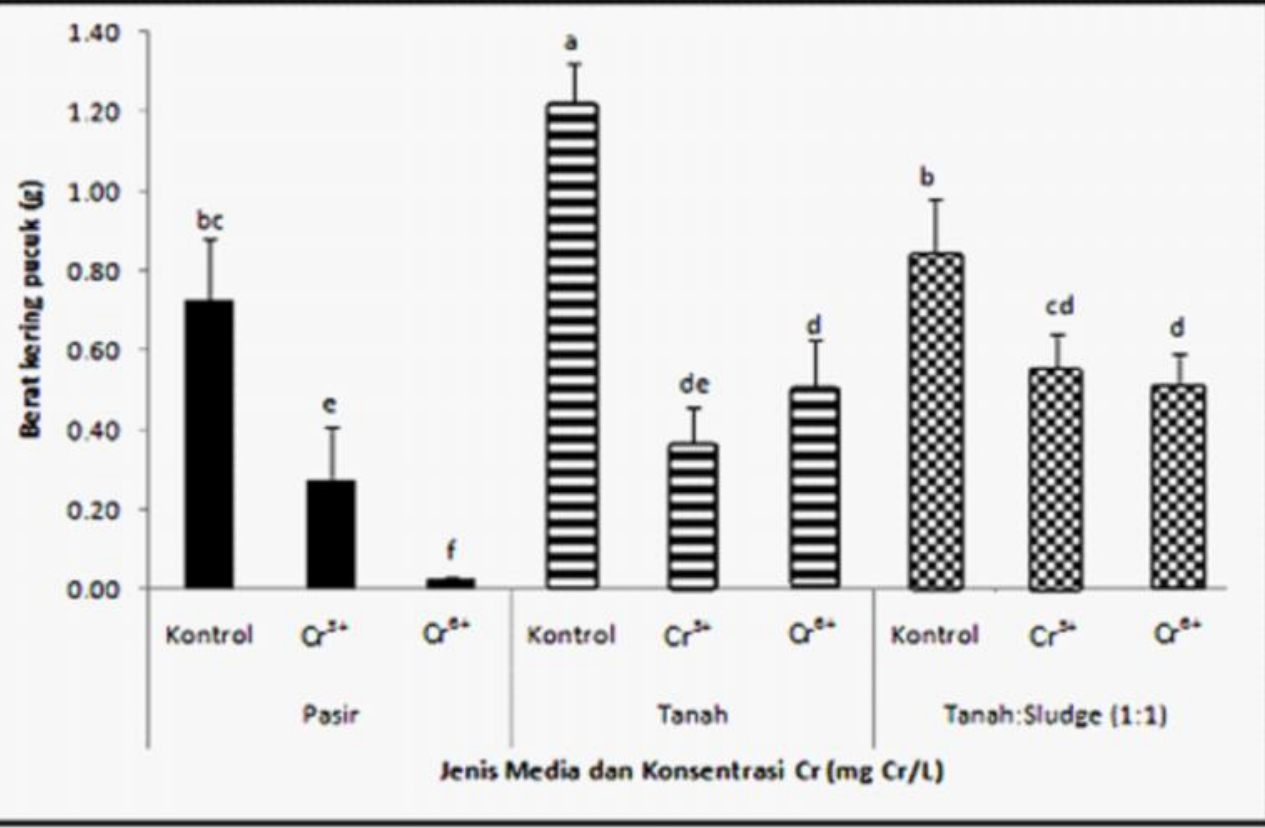

Gambar 2. Efek interaksi antara jenis media tanam dan perlakuan $\mathrm{Cr}$ terhadap biomassa kering akar (A) dan pucuk (B) tanaman S. oleraceus 
Seperti logam berat yang lain, krom yang terakumulasi di dalam jaringan tumbuhan berpengaruh terhadap pertumbuhan dan aktivitas fisiologis. Menurut Srivastava dan Gupta (1996) toksisitas krom umumnya menghambat pertumbuhan memanjang akar dan tunas, serta menginduksi terjadinya klorosis pada daun. Sun dan Wu (1998) melaporkan bahwa Ipomoea aquatica Forsk. cv. Bamboo-Leaf mengalami klorosis pada perlakuan $\mathrm{Cr}^{6+}$ sebesar 1,25 ppm. Pada konsentrasi lebih dari $1,25 \mathrm{ppm}$ (5 dan $10 \mathrm{ppm})$, tanaman mengalami penghambatan pertumbuhan, akar mengalami nekrosis, daun layu dan jumlah tunas berkurang. Toksisitas krom terhadap tanaman sangat ditentukan oleh bentuk species kimia dari unsur tersebut. Krom dalam bentuk $\mathrm{Cr}^{6+}$ bersifat lebih toksik terhadap tanaman dibandingkan bentuk $\mathrm{Cr}^{3+}$. Menurut Gundersen dkk. (1982) fitotoksisitas $\mathrm{Cr}^{6+}$ lebih besar dibanding $\mathrm{Cr}^{3+}$ dan penyerapan (uptake) $\mathrm{Cr}$ dari tanah meningkat sejalan dengan peningkatan konsentrasi Cr dalam tanah. Tanaka dkk. (1980) menyatakan bahwa pada konsentrasi tertentu $\mathrm{Cr}^{6+}$ lebih membahaya- kan dibanding $\mathrm{Cr}^{3+}$. Srivastava dkk. (1999) melaporkan bahwa pada dosis sebesar 150-300 $\mathrm{mg} / \mathrm{ml}, \mathrm{Cr}^{6+}$ lebih toksik terhadap Allium cepa dibanding $\mathrm{Cr}^{3+}$. Efek toksik krom terhadap tumbuhan tidak lepas dari akumulasi logam berat ini di dalam jaringan.

\section{Kandungan $\mathrm{Cr}^{6+}$ dan $\mathrm{Cr}$ total}

Akumulasi $\mathrm{Cr}^{6+}$ dan $\mathrm{Cr}$ total di dalam jaringan tanaman sonchus diukur untuk mengetahui seberapa besar kemampuannya menyerap, mentoleransi dan mentraslokasi $\mathrm{Cr}$ yang diserap ke bagian tanaman. Akumulasi $\mathrm{Cr}^{6+}$ di dalam jaringan/ organ tanaman dapat juga menjadi indikator kemampuan suatu tanaman untuk mendetoksifikasi logam $\mathrm{Cr}$, karena apabila tanaman terdeteksi mengakumulasi $\mathrm{Cr}^{6+}$ dalam tubuhnya dan tidak mengalami gangguan pertumbuhan, hal ini menunjukkan bahwa tanaman memiliki kemampuan untuk medetoksifikasi atau mentoleransi logam $\mathrm{Cr}^{6+}$ tersebut.

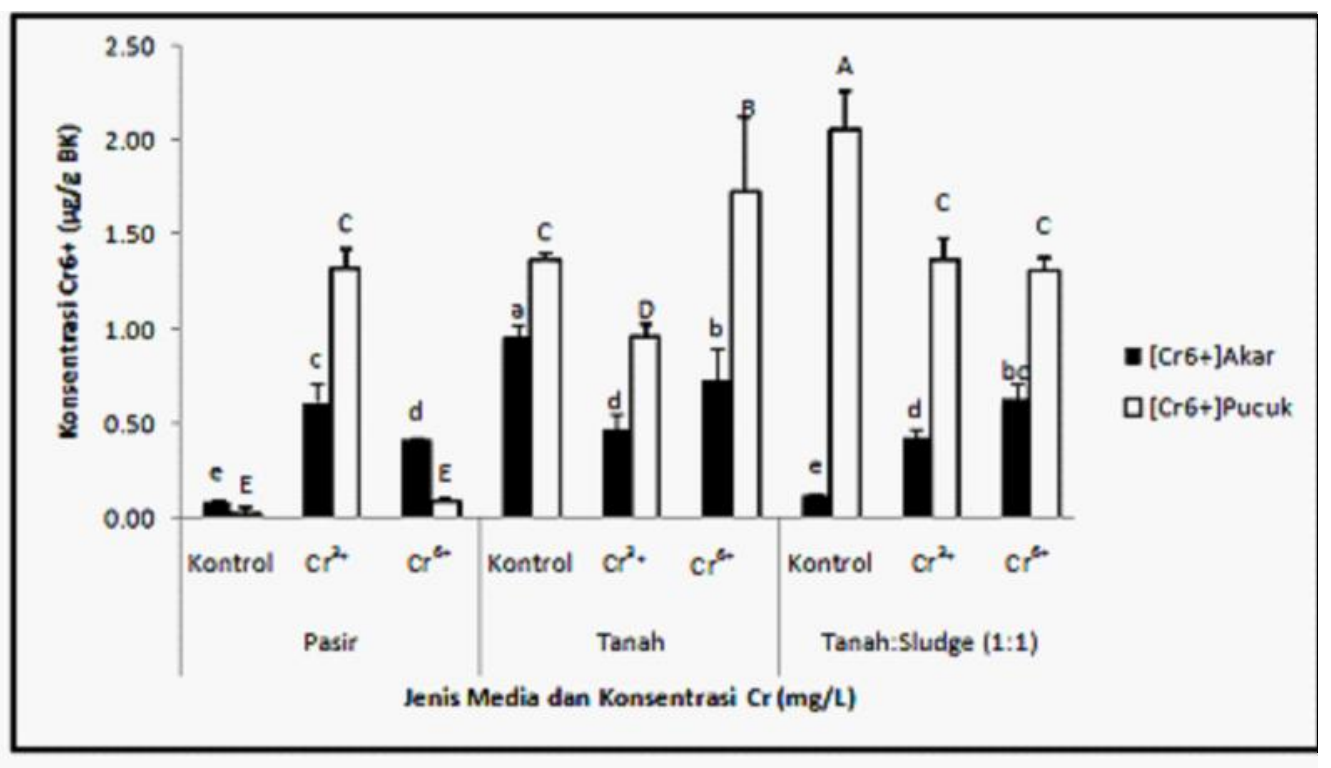

Gambar 3. Efek interaksi antara jenis media tanam dan perlakuan $\mathrm{Cr}$ terhadap konsentrasi $\mathrm{Cr}^{6+}$ dalam akar dan daun S. oleraceus 
Gambar 3 menunjukkan bahwa perlakuan $\mathrm{Cr}$ dan media tanam pada $S$. oleraceus memberikan pengaruh nyata terhadap akumulasi $\mathrm{Cr}^{6+}$ pada akar dan pucuk. Akumulasi Cr6+ lebih banyak terdeteksi di bagian pucuk dibanding di dalam akar, terutama pada $S$. oleraceus yang ditumbuhkan dalam media tanah dan campuran tanah:sludge tekstil. Sonchus yang ditumbuhkan pada media pasir menunjukkan akumulasi $\mathrm{Cr}^{6+}$ lebih kecil dibandingkan yang ditumbuhkan pada media tanah dan campuran tanah:sludge tekstil terutama yang diberi perlakuan $\mathrm{Cr}^{6+}$. Rendahnya akumulasi $\mathrm{Cr}^{6+}$ pada pucuk $S$. oleraceus yang ditanam pada media pasir mengandung $\mathrm{Cr}^{6+}$ disebabkan oleh ketidakmampuan akar untuk mentoleransi toksisitas $\mathrm{Cr}^{6+}$, hal ini ditunjukkan dengan paling rendahnya biomassa basah dan kering dari akar dan lebih lanjut berdampak pada biomassa pucuk. Selain itu, dengan aktifnya sistem antioksidan pada tanaman sonchus yang ditanam pada media pasir untuk merespon cekaman toksisitas $\mathrm{Cr}^{6+}$ juga dapat menghambat terjadinya translokasi $\mathrm{Cr}^{6+} \mathrm{ke}$ bagian pucuk. Hal ini ditunjukkan daun sonchus yang ditumbuhkan pada media pasir, cenderung lebih tinggi dibanding pada media tanah dan campuran tanah:sludge tekstil.
Berbeda dengan pola akumulasi $\mathrm{Cr}^{6+}$, akumulasi Cr total dalam akar tanaman paling tinggi ditunjukkan pada tanaman yang ditumbuhkan pada media pasir yang diberi perlakuan $\mathrm{Cr}^{3+}$ dan $\mathrm{Cr}^{6+}$ (Gambar 4). Hasil ini juga mendukung rendahnya akumulasi $\mathrm{Cr}^{6+}$ di bagian pucuk dari tanaman sonchus yang ditanam pada media pasir.

Terdeteksinya $\mathrm{Cr}^{6+}$ dalam akar dan pucuk tanaman sonchus yang ditumbuhkan pada media pasir, menunjukkan bahwa meskipun $\mathrm{Cr}^{3+}$ dianggap kurang toksik dibanding $\mathrm{Cr}^{6+}$, namun di dalam media dapat mengalami transformasi menjadi $\mathrm{Cr}^{6+}$ yang bersifat toksik. Reaksi oksidasi $\mathrm{Cr}$ di dalam tanah dan perairan alami tergantung pada keberadaan senyawa oksidan. Senyawa oksidan utama yang terdapat di dalam tanah yang dapat mengoksidasi $\mathrm{Cr}^{3+}$ menjadi $\mathrm{Cr}^{6+}$ adalah $\mathrm{Mn}$ oksida. Oksidasi $\mathrm{Cr}^{3+}$ menjadi $\mathrm{Cr}^{6+}$ mempunyai dampak yang tidak menguntungkan bagi lingkungan. Proses oksidasi akan mengubah krom dari bentuk tidak larut, tidak toksik dan tidak berbahaya $\left(\mathrm{Cr}^{3+}\right)$ menjadi bentuk krom yang terlarut, toksik dan berbahaya $\left(\mathrm{Cr}^{6+}\right)$. James dan Bartlett (1983) melaporkan bahwa peningkatan penyerapan krom oleh tanaman kacang kapri yang diberi perlakuan $\mathrm{Cr}^{6+}$, disebabkan adanya

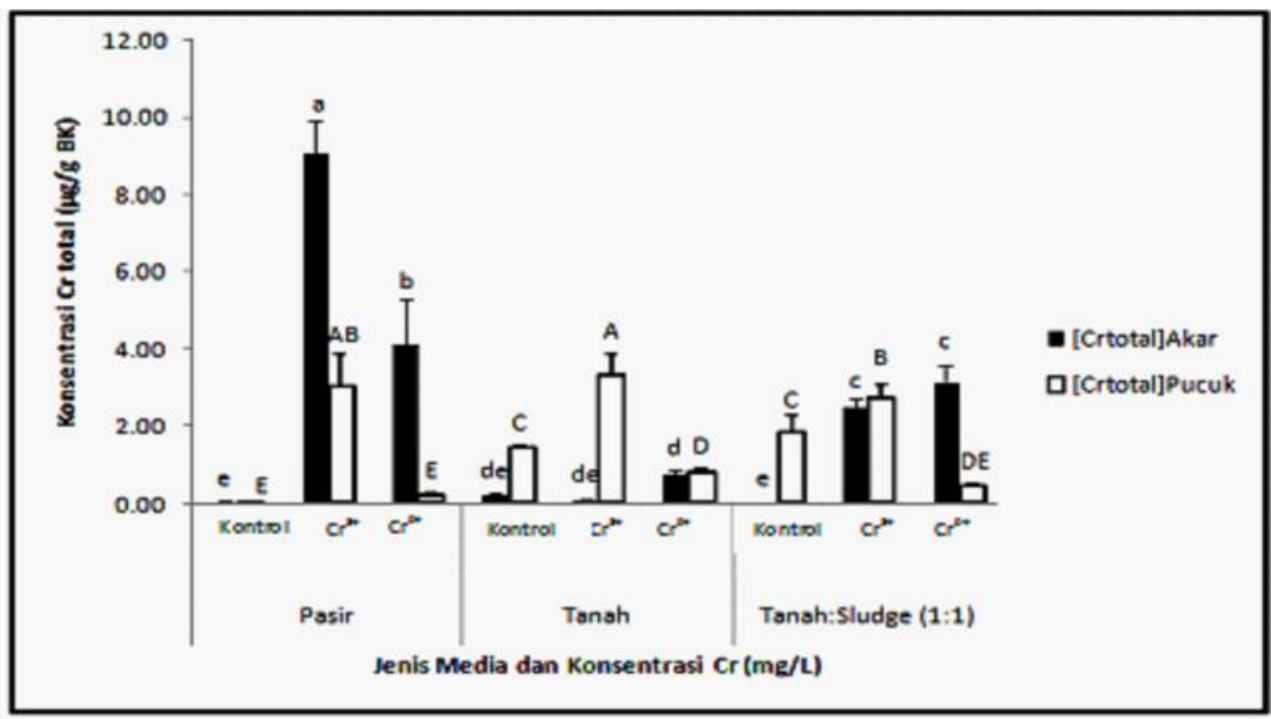

Gambar 4. Efek interaksi antara jenis media tanam dan perlakuan Cr terhadap konsentrasi Cr total dalam akar dan daun S. oleraceus 
peningkatan kelarutan $\mathrm{Cr}(\mathrm{OH})_{3}$ oleh sitrat dalam tanah yang meningkatkan laju oksidasi $\mathrm{Cr}^{3+}$ menjadi $\mathrm{Cr}^{6+}$ oleh oksida mangan dalam tanah.

\section{Deteksi dan penentuan radikal bebas}

Spesies oksigen reaktif (ROS) umumnya dihasilkan oleh sel melalui lintasan metabolisme aerobik dan merupakan respon terhadap berbagai cekaman abiotik maupun biotik. Berbagai spesies oksigen reaktif yang terbentuk sebagai salah satu terhadap adanya cekaman abiotik dan biotik antara lain $* \mathrm{O}_{2}^{-}, \mathrm{H}_{2} \mathrm{O}_{2}, \mathrm{OH}^{-}, * \mathrm{OH}$, dan oksigen singlet $\left({ }^{1} \mathrm{O}_{2}\right)$. Pembentukan ROS di dalam sel tumbuhan mempunyai dua fungsi utama yaitu (1) sebagai signal intrinsik untuk proses-proses pertumbuhan dan perkembangan dan (2) sebagai molekul signal untuk merespon adanya kondisi cekaman. ${ }^{*} \mathrm{O}_{2}$ dan $\mathrm{H}_{2} \mathrm{O}_{2}$ merupakan spesies oksigen reaktif yang dapat dijadikan sebagai indikator adanya kerusakan sel atau toksisitas serta munculnya reaksi pertahanan terhadap berbagai kondisi cekaman pada tumbuhan.

Pada penelitian ini ditentukan dua spesies oksigen reaktif yaitu $* \mathrm{O}_{2}^{-}$dan hidrogen $\mathrm{H}_{2} \mathrm{O}_{2}$ untuk mendeteksi terjadinya toksisitas dan munculnya reaksi pertahanan terhadap cekaman perlakuan Cr pada tanaman $S$. oleraceus. Salah satu pengaruh cekaman logam berat terhadap tumbuhan adalah menyebabkan terjadinya cekaman oksidatif, dan logam berat $\mathrm{Cr}$ merupakan salah satu logam yang bersifat redoks aktif dan dapat memacu munculnya cekaman oksidatif pada sel tumbuhan. Berdasarkan hasil penentuan level $\mathrm{H}_{2} \mathrm{O}_{2}$ dan $* \mathrm{O}_{2}^{-}$ ditunjukkan bahwa jenis media tanam dan perlakuan $\mathrm{Cr}\left(\mathrm{Cr}^{6+} 10 \mathrm{ppm}\right.$ dan $\left.\mathrm{Cr}^{3+} 250 \mathrm{ppm}\right)$ mempengaruhi level kedua spesies oksigen reaktif tersebut (Tabel 1). Tanaman S. oleraceus yang ditumbuhkan pada media pasir memproduksi ${ }^{*} \mathrm{O}_{2}^{-}$ dan $\mathrm{H}_{2} \mathrm{O}_{2}$ lebih tinggi berturut-turut $\left(0.89 \mathrm{Aë}_{580} / \mathrm{g}\right.$ $\mathrm{BB}$ dan $3.23 \mu \mathrm{mol} / \mathrm{g} \mathrm{BB})$ dibandingkan pada media tanah $\left(0.23 \mathrm{Aë}_{580} / \mathrm{g} \mathrm{BB}\right.$ dan $2.11 \mu \mathrm{mol} / \mathrm{g}$ $\mathrm{BB})$ dan tanah mengandung sludge tekstil (0.18 $\mathrm{Ae}_{580} / \mathrm{g} \mathrm{BB}$ dan $\left.2.66 \mu \mathrm{mol} / \mathrm{g} \mathrm{BB}\right)$.

Penambahan $\mathrm{Cr}^{6+}$ sebesar $10 \mathrm{mg} \mathrm{Cr}^{6+} / \mathrm{L}$ dan $\mathrm{Cr}^{3+}$ sebesar $250 \mathrm{mg} \mathrm{Cr}^{3+} / \mathrm{L}$ meningkatkan secara nyata pembentukan $* \mathrm{O}_{2}^{-}$dan $\mathrm{H}_{2} \mathrm{O}_{2}$ dalam daun S. oleraceus dibandingkan dengan kontrol (tanpa perlakuan $\mathrm{Cr}$ ). Hasil ini menunjukkan bahwa penambahan $\mathrm{Cr}$ dalam media tanam memberikan kondisi cekaman terhadap pertumbuhan $S$. oleraceus sehingga spesies oksigen reaktif $\left({ }^{*} \mathrm{O}_{2}^{-}\right.$dan $\left.\mathrm{H}_{2} \mathrm{O}_{2}\right)$ dibentuk sebagai signal untuk memunculkan reaksi pertahanan antioksidatif. Pengaktifan sistem pertahanan antioksidatif dilakukan melalui pembentukan

Tabel 1. Level $* \mathrm{O}_{2}^{-}$dan $\mathrm{H}_{2} \mathrm{O}_{2}$ daun $S$. oleraceus pada perlakuan $\mathrm{Cr}$ dan media tanam

\begin{tabular}{|c|c|c|c|c|}
\hline \multicolumn{5}{|c|}{ Level anion superoksida $\left(* \mathrm{O}_{2}^{-}\right)\left(\mathbf{A}_{\lambda 580} / \mathbf{g} \mathbf{B B}\right)$} \\
\hline Perlakuan & Pasir & Tanah & Tanah:Sludge(1:1) & Rata-rata \\
\hline Kontrol & $0.18 \pm 0.018 \mathrm{~cd}$ & $0.21 \pm 0.028 \mathrm{c}$ & $0.09 \pm 0.010 \mathrm{~d}$ & $0.16 \pm 0.038 \mathrm{C}$ \\
\hline $\mathrm{CrCl}_{3} 250 \mathrm{mg} \mathrm{Cr}^{3+} / \mathrm{L}$ & $0.53 \pm 0.061 \mathrm{~b}$ & $0.25 \pm 0.023 \mathrm{c}$ & $0.21 \pm 0.028 \mathrm{c}$ & $0.33 \pm 0.100 \mathrm{~B}$ \\
\hline $\mathrm{K}_{2} \mathrm{Cr}_{2} \mathrm{O}_{7} 10 \mathrm{mg} \mathrm{Cr}^{6+} / \mathrm{L}$ & $1.96 \pm 0.059 \mathrm{a}$ & $0.22 \pm 0.026 \mathrm{~cd}$ & $0.25 \pm 0.023 \mathrm{c}$ & $0.81 \pm 0.575 A$ \\
\hline Rata-rata & $0.89 \pm 0.542 \mathrm{~A}$ & $0.23 \pm 0.013 \mathrm{~B}$ & $0.18 \pm 0.048 \mathrm{~B}$ & \\
\hline \multicolumn{5}{|c|}{ Level $\mathrm{H}_{2} \mathrm{O}_{2}(\mu \mathrm{mol} / \mathrm{g} \mathrm{BB})$} \\
\hline Perlakuan & Pasir & Tanah & Tanah:Sludge(1:1) & Rata-rata \\
\hline $\mathrm{CrCl}_{3} 250 \mathrm{mg} \mathrm{Cr}^{3+} / \mathrm{L}$ & $1.80 \pm 0.208 \mathrm{e}$ & $2.36 \pm 0.092 \mathrm{c}$ & $2.20 \pm 0.176 \mathrm{~d}$ & $2.12 \pm 0.167 \mathrm{C}$ \\
\hline $\mathrm{K}_{2} \mathrm{Cr}_{2} \mathrm{O}_{7} 10 \mathrm{mg} \mathrm{Cr}^{6+} / \mathrm{L}$ & $3.31 \pm 0.331 b$ & $2.07 \pm 0.184 \mathrm{c}$ & $2.87 \pm 0.089 \mathrm{c}$ & $2.75 \pm 0.364 \mathrm{~B}$ \\
\hline $\mathrm{CrCl}_{3} 250 \mathrm{mg} \mathrm{Cr}^{3+} / \mathrm{L}$ & $4.58 \pm 0.212 \mathrm{a}$ & $1.89 \pm 0.239 \mathrm{~cd}$ & $2.90 \pm 0.161 \mathrm{c}$ & $3.12 \pm 0.787 \mathrm{~A}$ \\
\hline Rata-rata & $3.23 \pm 0.804 \mathrm{~A}$ & $2.11 \pm 0.139 \mathrm{C}$ & $2.66 \pm 0.277 \mathrm{~B}$ & \\
\hline
\end{tabular}


kandungan antioksidan dan pengaktifan enzim antioksidatif dalam daun.

Pengaruh interaksi antar perlakuan terhadap level ${ }^{*} \mathrm{O}_{2}^{-}$dan $\mathrm{H}_{2} \mathrm{O}_{2}$ daun terlihat nyata hanya pada penambahan $\mathrm{Cr}^{6+}$ sebesar $10 \mathrm{mg} \mathrm{Cr} \mathrm{Cr}^{6+} / \mathrm{L}$ baik pada media pasir, tanah maupun tanah mengandung sludge tekstil. Deteksi keberadaan ${ }^{*} \mathrm{O}_{2}^{-}$ dilakukan dengan reaksi histokimia menggunakan senyawa NBT (nitrotetrazolium blue chloride) sebagai substrat kromogenik. Teknik ini dapat diterapkan secara langsung untuk mendeteksi pembentukan $* \mathrm{O}_{2}^{-}$dalam jaringan, sel maupun subseluler secara in vivo dan dideteksi secara mikroskopis. NBT akan bereaksi dengan ${ }^{*} \mathrm{O}_{2}^{-}$ endogen membentuk senyawa formazan tak larut yang berwarna biru keunguan. Hasil deteksi histokimia $* \mathrm{O}_{2}^{-}$dalam jaringan daun $S$. oleraceus pada perlakuan $\mathrm{Cr}$ dan media tanam ditunjukkan pada Gambar 5.

Berdasarkan hasil deteksi histokimia $* \mathrm{O}_{2}^{-}$dalam daun $S$. oleraceus menggunakan NBT, ditunjukkan bahwa daun dari tanaman yang ditumbuhkan pada media pasir dan campuran tanah:sludge tekstil (1:1) yang diberi perlakuan $\mathrm{Cr}\left(\mathrm{Cr}^{3+}\right.$ maupun $\left.\mathrm{Cr}^{6+}\right)$ memberikan reaksi positif yang lebih tinggi dibandingkan pada tanah. Reaksi positif ditunjukkan oleh terbentuknya bercakbercak biru-ungu (senyawa formazan tidak larut) sebagai akibat reaksi NBT dengan $* \mathrm{O}_{2}^{-}$. Lingkaran biru yang terdapat tepi irisan daun sebelah

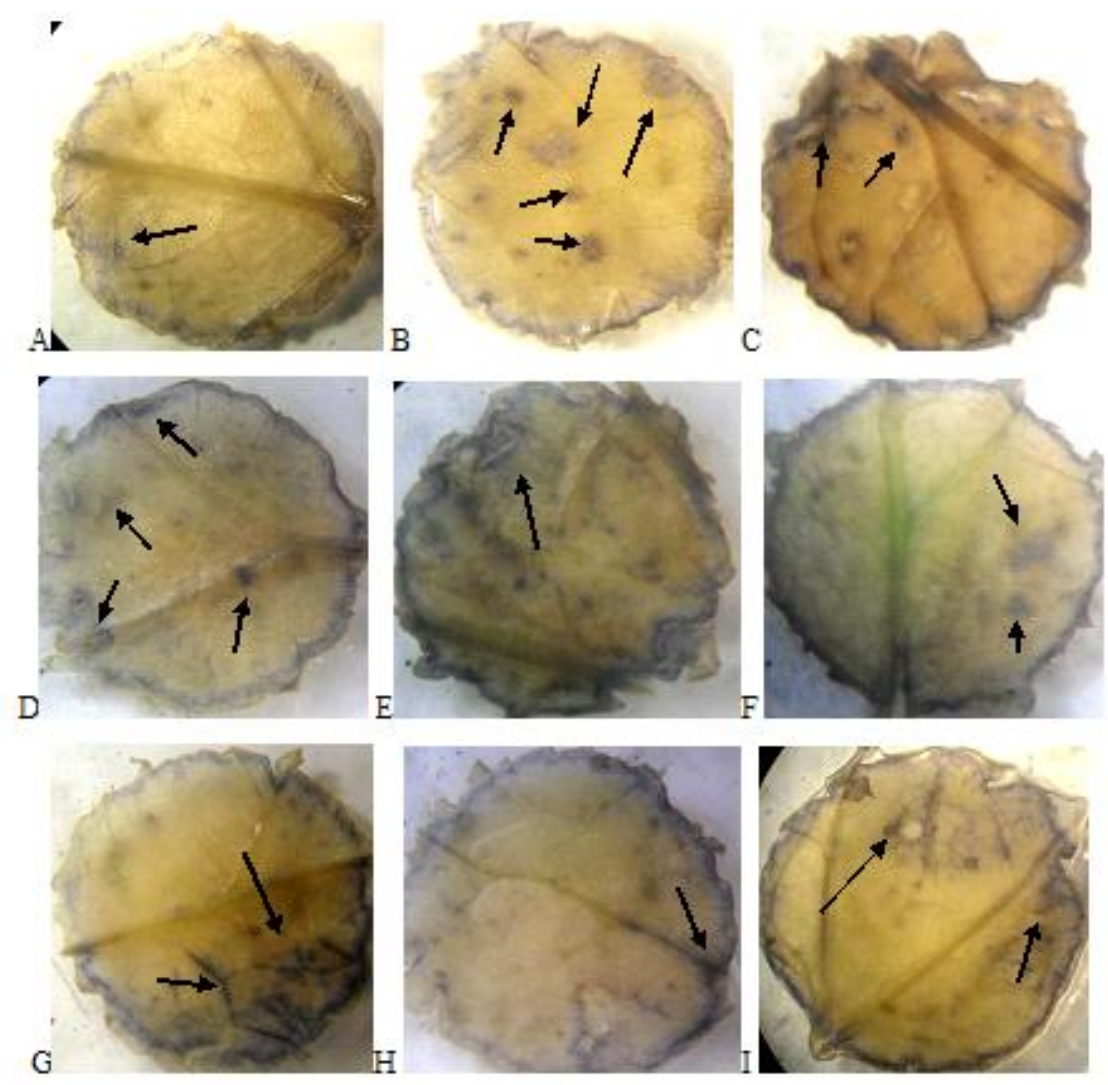

Gambar 5. Deteksi histokimia lokasi pembentukan $* \mathrm{O}_{2}^{-}$pada jaringan daun $S$. oleraceus yang ditanam pada media pasir (A. kontrol, B. $\mathrm{Cr}^{3+} 250 \mathrm{mg} \mathrm{Cr}{ }^{3+} / \mathrm{L}$, dan C. $\mathrm{Cr}^{6+} 10 \mathrm{mg} \mathrm{Cr}{ }^{6+} / \mathrm{L}$ ), tanah:sludge tekstil (1:1) (D. kontrol, E. Cr ${ }^{3+} 250 \mathrm{mg} \mathrm{Cr}{ }^{3+} / \mathrm{L}$, dan $\mathrm{F} \mathrm{Cr}^{6+} 10 \mathrm{mg} \mathrm{Cr}^{6+} / \mathrm{L}$ ) dan tanah (G. kontrol, H. $\mathrm{Cr}^{3+} 250 \mathrm{mg} \mathrm{Cr}^{3+} / \mathrm{L}$, dan I. $\left.\mathrm{Cr}^{6+} 10 \mathrm{mg} \mathrm{Cr}^{6+} / \mathrm{L}\right)$. Tanda panah menunjukkan daerah reaksi positif dengan NBT (terjadi pembentukan $* \mathrm{O}_{2}^{-}$) 
luar baik pada kontrol dan perlakuan $\mathrm{Cr}$ untuk ketiga jenis media tanam menunjukkan terbentuknya $* \mathrm{O}_{2}^{-}$sebagai respon terhadap pelukaaan saat pengirisan daun. Bercak biru gelap pada daun S. oleraceus belum terlihat jelas, diduga NBT yang digunakan kurang konsentrasinya atau kurang lama meredamnya sehingga reaksi oksidasi NBT oleh ${ }^{*} \mathrm{O}_{2}^{-}$belum sering terjadi. Menurut Lin dkk. (2009) NBT dalam merupakan probe yang sesuai dan bernilai penting untuk memonitoring pembentukan $\mathrm{O}_{2}^{-}$pada tumbuhan.

Selain $* \mathrm{O}_{2}^{-}$, deteksi $\mathrm{H}_{2} \mathrm{O}_{2}$ dalam jaringan/organ juga dapat dilakukan dengan menggunakan pewarna DAB sebagai probe dye-nya. Menurut Kumar dkk. (2014) DAB akan dioksidasi oleh $\mathrm{H}_{2} \mathrm{O}_{2}$ oleh adanya enzim peroksidase dan akan menghasilkan warna coklat kemerahan (Gambar 6).
Di dalam penelitian ini deteksi $\mathrm{H}_{2} \mathrm{O}_{2}$ hanya dilakukan melalui pengukuran secara spektrofotometris jumlah $\mathrm{H}_{2} \mathrm{O}_{2}$ yang terbentuk di dalam daun. $\mathrm{H}_{2} \mathrm{O}_{2}$ dan $* \mathrm{O}_{2}^{-}$merupakan dua spesies oksigen reaktif yang dapat digunakan sebagai indikator adanya kerusakan atau toksisitas di dalam sel, serta sebagai indikator munculnya reaksi pertahanan terhadap berbagai kondisi cekaman lingkungan. Deteksi histokimia akumulasi $\mathrm{H}_{2} \mathrm{O}_{2}$ dan $* \mathrm{O}_{2}^{-}$menggunakan probe dye DAB dan NBT pada jaringan tumbuhan sangat berpotensi dikembangkan untuk memonitoring terjadinya cekaman oksidatif pada tumbuhan baik yang diakibatkan oleh adanya cekaman abiotik maupun biotik.

Metode deteksi histokimia ini dapat diterapkan pada semua jenis tumbuhan mulai pada tingkat

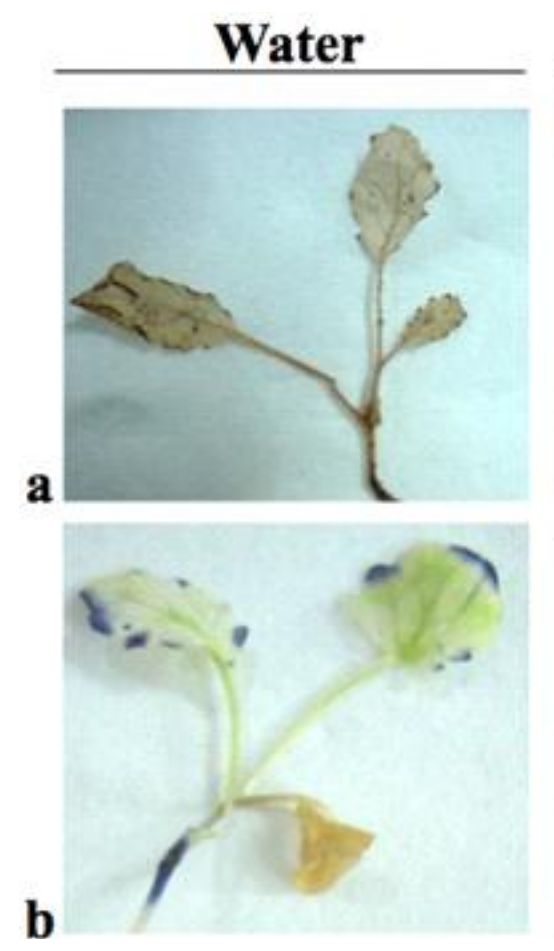

\section{$200 \mathrm{mM} \mathrm{NaCl}$}
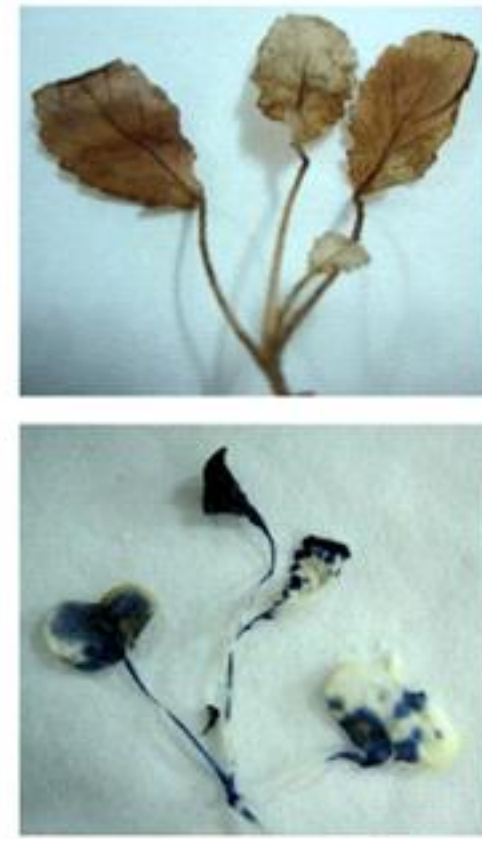

Gambar 6. Deteksi akumulasi $\mathrm{H}_{2} \mathrm{O}_{2}$ (a) dan $* \mathrm{O}_{2}^{-}$(b) pada kecambah Brassica juncea yang diberi perlakuan cekaman salinitas $200 \mathrm{mM}$ NaCl selama 3 hari. Kecambah yang ditumbuhkan dalam media air digunakan sebagai kontrol (Kumar dkk., 2014) 
sel, jaringan maupun organ. Deteksi pembentukan ${ }^{*} \mathrm{O}_{2}^{-}$menggunakan NBT assay telah dilakukan pada sel tunggal tembakau yang mengalami respon hipersensitif (Adam dkk. 1989), pada daun Arabidopsis yang diberi cekaman cahaya (Fryer dkk. 2002), pada daun tembakau yang diberi cekaman ozon (Schraudner dkk., 1998), dan pada daun Pisum sativum yang diberi cekaman salinitas (Hernandez dkk. 2001). Malecka dkk. (2014) melaporkan juga penggunaan NBT assay untuk mendeteksi pembentukan $* \mathrm{O}_{2}^{-}$pada akar Pisum sativum yang diberi perlakuan kombinasi cekaman 2 logam berat $(\mathrm{Cu}, \mathrm{Zn}, \mathrm{Cd}$ dan $\mathrm{Pb})$. Lin dkk. (2009) melaporkan penggunaan deteksi histokimia (NBT assay) untuk pengukuran $* \mathrm{O}_{2}^{-}$ secara lokalisasi in situ pada daun Alocasia macrorrhiza yang diberi perlakuan berbagai faktor stress antara lain fotooksidan (methyl viologen dan riboflavin), polutan (sodium bisulfit, logam berat $\mathrm{Pb}$ dan $\mathrm{Cd}$ ), serta kekeringan (PEG $6000)$.

\section{Korelasi antara Akumulasi $\mathrm{Cr}$ dengan Pertum-buhan dan Terbentuknya Radikal Bebas}

Analisis korelasi dilakukan untuk mengetahui signifikansi hubungan antara parameter akumulasi logam berat $\mathrm{Cr}$ dalam media dan jaringan tanaman sonchus dengan pertumbuhan dan pembentukan radikal bebas $\left(\mathrm{H}_{2} \mathrm{O}_{2}\right.$ dan $\left.* \mathrm{O}_{2}^{-}\right)$di bagian daun tanaman. Berdasarkan hasil analisis korelasi Pearson's pada Tabel 2 ditunjukkan bahwa kandungan $\mathrm{Cr}^{6+}$ dan $\mathrm{Cr}$ total dalam akar dan daun menunjukan korelasi dengan pertumbuhan dan pembentukan radikal bebas $\left(\mathrm{H}_{2} \mathrm{O}_{2}\right.$ dan $\left.* \mathrm{O}_{2}^{-}\right)$.

Akumulasi $\mathrm{Cr}^{6+}$ dan $\mathrm{Cr}$ total di dalam akar berkorelasi positif dengan terbentuknya radikal bebas $\mathrm{H}_{2} \mathrm{O}_{2}$, sebaliknya akumulasi $\mathrm{Cr}\left(\mathrm{Cr}^{6+}\right.$ dan total) di dalam pucuk berkorelasi negatif dengan radikal bebas $\mathrm{H}_{2} \mathrm{O}_{2}$. Pembentukan $* \mathrm{O}_{2}^{-}$berkorelasi negatif dengan akumulasi $\mathrm{Cr}^{6+}$ baik di

Tabel 2. Korelasi (Pearson's) antara akumulasi Cr dengan pertumbuhan dan terbentuknya radikal bebas pada gulma sonchus

\begin{tabular}{|c|c|c|c|c|c|c|c|c|c|c|}
\hline & H2O2 & $* \mathbf{O}_{2}^{-}$ & Cr6A & Cr6P & CrTA & CrTP & BBA & BBP & BKA & BKP \\
\hline $\begin{array}{l}\mathrm{H} 2 \mathrm{O} \\
2\end{array}$ & 1,000 & & & & & & & & & \\
\hline$* \mathrm{O}_{2}^{-}$ & $0,779^{* *}$ & 1,000 & & & & & & & & \\
\hline Cr6A & 0,069 & $-0,038$ & 1,000 & & & & & & & \\
\hline Cr6P & $-0,301^{*}$ & $-{ }^{-}, 572^{* *}$ & $0,302^{*}$ & 1,000 & & & & & & \\
\hline $\begin{array}{l}\text { CrT } \\
\text { A }\end{array}$ & $0,598^{* *}$ & $0,402^{* *}$ & 0,175 & $-0,057$ & 1,000 & & & & & \\
\hline CrTP & $-0,130$ & $-0,280$ & 0,084 & $\begin{array}{l}0,393^{*} \\
*\end{array}$ & 0,210 & 1,000 & & & & \\
\hline BBA & $-0,269$ & $-\overline{0,453^{* *}}$ & ${ }_{*}^{0,791^{*}}$ & $0,373^{*}$ & 0,046 & 0,048 & 1,000 & & & \\
\hline BBP & $-\overline{0,618^{* *}}$ & $-\bar{c}, 711^{* * *}$ & 0,271 & $0,541^{*}$ & $-\overline{0}, 600^{* *}$ & $-\overline{0}$ & $0,529^{*}$ & 1,000 & & \\
\hline BKA & $-0,122$ & $-0,276$ & 0,633* & 0,151 & 0,018 & 0,002 & * $0,714^{*}$ & $0,416^{*}$ & 1,000 & \\
\hline BKP & $\begin{array}{l}- \\
0,566^{* *}\end{array}$ & $\overline{-}^{0,650^{* * *}}$ & 0,164 & $0,369^{*}$ & $\overline{-}^{0,572^{* *}}$ & $\begin{array}{l}- \\
0,059\end{array}$ & $0,521^{*}$ & $0,868^{*}$ & * $0,501^{*}$ & $\begin{array}{l}1,00 \\
0\end{array}$ \\
\hline
\end{tabular}

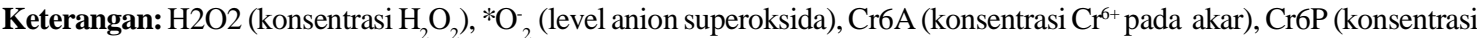
$\mathrm{Cr}^{6+}$ pada pucuk), $\mathrm{CrTA}$ (konsentrasi $\mathrm{Cr}$ total pada akar), $\mathrm{CrTP}$ (konsentrasi $\mathrm{Cr}$ total pada pucuk), BBA(Berat basah akar), BBP (Berat basah pucuk), BKA (Berat kering akar), BKP (Berat kering pucuk).

** Korelasi signifikan pada tingkat signifikansi $1 \%$

* Korelasi signifikan pada tingkat signifikansi 5\%

Listwise $\mathrm{N}=45$ 
dalam akar dan pucuk, serta Cr total dalam pucuk. Korelasi positif dijumpai antara akumulasi Cr total di dalam pucuk dengan $* \mathrm{O}_{2}^{-}$. Adanya korelasi baik positif maupun negatif antara akumulasi $\mathrm{Cr}^{6+} \mathrm{dan}$ Cr total di dalam akar dan pucuk gulma sonchus menunjukkan bahwa $\mathrm{Cr}$ dalam organ tanaman punya efek besar dalam memunculkan terjadinya stress oksidatif pada tanaman. Stress oksidatif akibat terbentuknya radikal bebas ini, selanjutnya berdampak negatif terhadap pertumbuhan tanaman, semakin tinggi radikal bebas terbentuk akan semakin menurunkan biomassa tanaman. Hal ini didukung oleh hasil analisis korelasi Pearson yang menunjukkan bahwa ada korelasi negatif antara pembentukan radikal bebas baik dalam bentuk $* \mathrm{O}$ ${ }_{2}$ maupun $\mathrm{H}_{2} \mathrm{O}_{2}$ dengan biomassa basah dan kering tanaman.

Akumulasi $\mathrm{Cr}^{6+}$ dalam akar dan pucuk berkorelasi positif terhadap berat basah dan berat kering tanaman (akar dan pucuk), hal ini menunjukkan bahwa semakin besar akumulasi $\mathrm{Cr}^{6+}$ di dalam akar dan daun, biomassa basah dan kering akar serta pucuk semakin meningkat pula. Peningkatan biomassa diduga sebagai salah satu strategi untuk dapat bertahan hidup dan mentoleransi toksisitas Cr. Akumulasi Cr total dalam akar dan pucuk berkorelasi positif dengan biomassa basah dan kering akar, namun berkorelasi negatif dengan biomassa basah dan kering bagian pucuk. Banyaknya akumulasi Cr total di dalam akar dan pucuk akan meningkatkan biomassa baik kering maupun basah bagian akar tanaman, hal ini bertujuan agar tanaman mampu bertahan hidup. Korelasi negatif secara nyata hanya ditunjukkan antara akumulasi Cr total akar dengan berat basah dan kering pucuk. Hasil ini menunjukkan bahwa penurunan pertumbuhan bagian pucuk gulma Sonchus secara nyata ditentukan oleh toksisitas Cr dalam akar. Akumulasi Cr di dalam akar akan mempengaruhi pertumbuhan tanaman secara keseluruhan apabila tidak ada proses detoksifikasi. Menurut Cobbett (2000) dan Liu \& Kottke (2003) pada umumnya sel-sel tanaman merespon stress logam berat menggunakan berbagai mekanisme pertahanan, di antaranya eksklusi, immobilisasi, khelasi, dan kompartementalisasi ion logam. Tanaman memiliki kemampuan untuk mencegah ion logam masuk secara berlebihan ke dalam sitosol dan mampu melokalisasi ion logam tersebut pada daerah tertentu. Kompartementasi ion di dalam vakuola merupakan mekanisme yang berperan penting dalam proses detoksifikasi dan toleransi terhadap ion logam. Pada gulma Sonchus diduga mekanisme detoksifikasi $\mathrm{Cr}$ melalui khelasi oleh senyawa antioksidan seperti glutathion atau senyawa thiol serta dengan kompartementasi di dalam akar dan daun.

\section{KESIMPULAN}

Akumulasi $\mathrm{Cr}$ baik dalam bentuk $\mathrm{Cr}$ trivalen maupun heksavalen dapat menyebabkan terjadinya cekaman oksidatif pada tanaman sonchus baik yang ditumbuhkan pada media pasir, tanah maupun campuran tanah:sludge tekstil, hal ini ditunjukkan dengan terdeteksinya peningkatan pembentukan $\mathrm{H}_{2} \mathrm{O}_{2}$ dan $* \mathrm{O}_{2}^{-}$pada daun gulma yang diberi perlakuan Cr. Pembentukan $\mathrm{H}_{2} \mathrm{O}_{2}$ dan $* \mathrm{O}_{2}^{-}$paling tinggi dijumpai pada daun gulma S. oleraceus yang ditumbuhkan pada media pasir dengan perlakuan $\mathrm{Cr}^{6+}$. Akumulasi $\mathrm{Cr}^{6+}$ dan $\mathrm{Cr}$ total di dalam akar dan pucuk menunjukkan korelasi dengan pembentukan radikal bebas $\mathrm{H}_{2} \mathrm{O}_{2}$ dan ${ }^{*} \mathrm{O}_{2}^{-}$pada daun gulma Sonchus. NBT merupakan probe yang dapat digunakan untuk memonitoring pembentukan $* \mathrm{O}_{2}^{-}$pada daun gulma $S$. oleraceus. Stress oksidatif akibat toksisitas $\mathrm{Cr}$ mempengaruhi secara nyata biomassa kering dan basah tanaman Sonchus. Perbedaan jenis media tanam mempengaruhi cekaman oksidatif yang ditimbulkan oleh $\mathrm{Cr}$ pada gulma Sonchus, terutama dalam hal pembentukan $\mathrm{H}_{2} \mathrm{O}_{2}$ dan $* \mathrm{O}_{2}^{-}$. Cekaman oksidatif paling tinggi dijumpai pada gulma Sonchus yang ditumbuhkan pada media pasir steril. 


\section{UCAPAN TERIMA KASIH}

Penelitian dan publikasi hasil penelitian ini terlaksana atas bantuan pendanaan DIKTI melalui program Hibah Bersaing Tahun 2014.

\section{DAFTAR PUSTAKA}

Adam, A., Farkas, T., Somlyai, G., Hevesi, M., and Kiraly, Z. 1989. Consequence of $\mathrm{O}_{2}$ generation during bacterialy induced hypersensitive reaction in tobacco: deterioration of membrane lipids. Physiol. Mol. Plant Pathol. 34:13-26

Bouazizi, H., Jouili, H., and Ferjani, E.E. 2007. Effects of copper excess on growth, $\mathrm{H}_{2} \mathrm{O}_{2}$ production and peroxidase activities in maize seedling (Zea mays). Pakistan Journal of Biological Sciences. No.10, Vol. 5:751-756. ISSN 1028-8880

Cobbett, C. S. 2000. Phytochelatins and their roles in heavy metal detoxification. Plant Physiology 123: 825-832.

Fryer, M.J., Oxborough, K., Mullineaux, P.M., and baker, N.R. 2002. Imaging of photooxidative stress responses in leaves. $J$. Exp. Bot. 53:1249-1254

Gundersen, P., C.B. Gunse and J. Barcelo, 1982. Phytotoxicological Effects of Chromium in Soil. Nordisk Jordbrugsforskning 64: 4,481 .

Herawati, M.M, S. Kasmiyati., S., dan E.B.E. Kristiani, 2008. Pengelolaan Limbah Padat Tekstil dengan metode Pengomposan dan Fitoremediasi. Laporan Hasil Penelitian Program Penelitian Teknologi Tepat Terpadu, Dinas Pendidikan dan Kebudayaan Provinsi Jawa Tengah (tidak dipublikasikan).

Hernandez, J.A., Ferrer, M.A., Jimenez, A., Barcelo, A.R., and Sevilla, F. 2001. Antioxidant systems and $\mathrm{O}_{2}-1 \mathrm{H}_{2} \mathrm{O}_{2}$ production in apoplast of pea leaves. Plant Physiol. 127:817-831.
James, B. R. and R. J. Bartlett. 1983. Behavior of chromium in soils: V. Fate of organically complexed Cr(II) added to soil. J. Environ. Qual. 12:169-172.

Kumar, D., Yusuf, M.A., Singh, P., Sardar, M. And Sarin, N.B. 2014. Histochemical detection of superoxide and $\mathrm{H}_{2} \mathrm{O}_{2}$ accumulation in Brassica juncea seedlings. http://www.bio-protocol.org/. 12 Juli 2014

Lin, Z.F., Liu, N., Lin, G.Z. and Peng, C.L. 2009. In situ localisation of superoxide generated in leaves of Alocasia macrorrhiza (L.) Shott under various stresses. J.Plant Biol. 52:340-347. DOI 10.1007/s12374-0099044-8.

Liu, D. and Kottke, I. 2003. Subcellular localization of chromium and nickel in root cells of Allium cepa by EELS and ESI. Cell Biology and Toxicology 19: 299-311

Malecka, A., Piechalak, A., Zielinska, B., Kutrowska, A., and Tomaszewska, B. 2014. Response of the pea roots defense systems to the two-element combinations of metals $(\mathrm{Cu}, \mathrm{Zn}, \mathrm{Cd}, \mathrm{Pb})$. Acta Biochimica Polonica. No. 1, Vol. 61:23-28. Online at: www.actabp.pl

, Derba-Marceluch, A., Kaczorowska, M., Piechalak, A., and Tomaszewska, B. 2009. ROS production and antioxidative defense system in pea root cells treated with lead ions. Part 2. Mitochondrial and peroxisomal level. Acta Physiol. Plant. 31:1065-1075

Panda S.K. and Patra, H.K. 2000. Does Cr(III) produces oxidative damage in excised wheat leaves. J. Plant Biol. 27(2):105110

2003. Heavy metal phytotoxicity induces oxidative stress in Taxithelium sp. Curr. Sci. 84: 631-633 
Schraudner, M., Moeder, W., Wiese, C., van Camp, W., Inze, D., Langebartels, C., and Sandermann, H. Jr. 1998. Ozone-induced oxidative burst in the ozone biomonitor plant, tobacco Bel W3. Plant J. 16:235245.

Shulaev, V. and Oliver D.J. 2006. Metabolic and proteomic markers for oxidative stress. New tools for reactive oxygen species research. Plant Physiol. 141:367-372.

Srivastava, P.C. and U.C. Gupta, 1996. Trace Elements In Crop Production. Science Publisher Inc. USA. pp. 226-230.

Srivastava, S., S. Prakash and M.M. Srivastava, 1999. Chromium Mobilization and Plant Availability - The Impact of Organic Complexing Ligands. Plant and Soil 212: 203-208.
Sun, E. and Wu, F. 1998. Along-vein Necrosis as Indicator Symptom on Water Spinach Caused by Nickel in Water Culture. Bot. Bull. Acad. Sin. 39:255-259.

Tanaka, A., T. Tadano and O. Hayakawa, 1980. Comparison of Adaptability to Heavy Metals among Crop Plants (V) Adaptability to Chromium-Studies on Comparative Plant Nutrition. Journal of the Science of Soil and Manure, Japan 51:2, 113-118.

Vianello, A., Zancani, M., Peresson, C., Petrussa, E., Casolo, V., Krajnakova, J., Patui, S., Braidot, E., and Marci, F. 2007. Plant mitochondrial pathway leading to programmed cell death. Physiol. Plant 129:242-252. 